\title{
Discussion on Practical Teaching System of Accounting Major in Independent Colleges
}

\author{
Haiyan Sun \\ Jincheng College \\ Nanjing University of Aeronautics and Astronautics \\ Nanjing, Jiangsu, China, 211156 \\ e-mail: shy2014@nuaa.edu.cn
}

\begin{abstract}
The number of students in accounting major of independent colleges has increased rapidly over the past few years. How to build the practical teaching system of accounting major and what to be done to develop the practical ability of students in this major, has become the problems of the teachers in accounting of independent colleges. Therefore, based on the studies on the practical teaching condition of accounting major in independent colleges, this paper figured out the problems that exist in its system and has put forward relevant countermeasures, which is of great practical significance.
\end{abstract}

Keywords-independent colleges; accounting major; practical teaching system

\section{INTRODUCTION}

At present, it is the main target for independent colleges to train applied talents that meet the markets' demands. Accounting major is a management subject of high technicality and expertise. This major in most of the independent colleges requires students not only to master its basic theories and accounting method, but also to equip with the practical ability of applying knowledge into work. Practical teaching is a bonding point of accounting theories and practical application. Meanwhile, it is of great significance in the teaching of accounting major at independent colleges. Thus, the development of practical teaching system of accounting major at independent colleges can help train the students' practical accounting ability and innovation capacity and raise the quality of the talents as well.

\section{The PROBLEMS EXIST IN THE CURRENT PRACTICAL TEACHING SYSTEM OF ACCOUNTING MAJOR AT INDEPENDENT COLLEGES}

Lecture is the main teaching approach of accounting major at independent colleges. Simulation laboratory has been built in independent colleges. At the same time, under the cooperation between these colleges and enterprises, a

Fund project: Phase result of The Optimization and Improvement of Practical Teaching System of Accounting ( Y2013-z-03), the Key Research project of Education and Teaching Reform in 2013 by Jincheng College of Nanjing University of Aeronautics and Astronautics. number of off-campus practice bases have been established. All these measures have provided condition for practical teaching and improved the students' practical ability to some extent. But there is still a long way to go for practical teaching to meet the needs of the society. Because the current practical teaching is still restricted to accountancy itself and has little connection to the related subjects, which has limited the depth and breadth and influenced the overall effect of practical teaching to a great degree. The main influences are as follow:

\section{A. The System of Practical Teaching is Not Systematic}

It is a competitive advantage of the accounting majors at independent colleges to have great practical ability and post upon graduation. However, the educational concept and pattern of many independent colleges is still like the condensed form of undergraduate schools'. There are disadvantages showed by practical teaching of accounting in this form. There is lacking systematic thinking in the arrangement of practical teaching, they still prefer theories to practices and their practical teaching is still based on the stimulated one. Those all have resulted in the poor knowledge of theories and weak practical ability of the graduates from independent colleges. Though many colleges have realized the importance of practical teaching to accounting majors and have strengthened their efforts to carry out practical teaching, they could not solve the problems fundamentally yet.

\section{B. The Content of Practical Teaching is Not Complete}

The content-setting of accounting practical teaching could not connect with the accounting practice work. It is reflected from the following things: First, practical teaching has not combined with the management system in the enterprises. We can rarely see role assignment in it and the checking and restraint of role assignment haven't been taken into consideration. The work from filling the original certificate to preparing statement is always done by a single student. Second, the transfer process of documents can not be reflected. During practical teaching, all the Stock Ins, Stock Outs and invoices are filled by student himself, in this case, the delivery of bills in each link does not exist at all. 


\section{Practical Teaching Method in Class is Not Flexible}

At the practical accounting class, students are required to learn knowledge, form skills, and cultivate innovative awareness and laboring emotion during the process of practice. However, the present practicing class mainly focuses on sermon, repeatedly stimulation or mechanically practicing. And they make the students do their assignment at stimulation practicing room and guide them timely. This single and fixed teaching method will limit the motivation and creativity of the students. If things continue this way, students will be tired of practical class.

\section{The Practical Experience of Teachers is Lack}

An experienced and well-constructed group of teachers plays a decisive role in making the accounting practical teaching receive expected effect. However, most of the teachers at independent colleges are lacking specific practical experience. In practical teaching, they direct students according to their own understanding. Meanwhile, they could not combine the theory with practice, which makes it an armchair strategist for practical teaching. Besides, there are not enough teachers in independent colleges. The teaching management systems of most colleges do not include requiring teachers to participate in social practice. There is no guarantee on time, organizing and expense to the teachers' participation in social practice. Therefore, most teachers do not have professional skills certificate. The proportion of double-certificated teachers who have both the theoretical knowledge and practical skills is far from enough.

\section{E. The Assessment Method is Fixed}

The accounting practice has many features. For example, there are many materials, data, and heavy work. Difficulties exist in assessment should be solved. Many teachers adopt the same assessment method. They give total scores to students according to their regular grades and final grades. If only they finish filling the bills, certificates and lists they will get the final score. And the regular grades are based on their attendance rate. In this way, some students will copy the work of others to get final scores, thus they can not receive desired effect.

\section{THE STRATEGIES TO IMPROVE THE PRACTICAL} TEACHING SYSTEM OF ACCOUNTING MAJOR IN INDEPENDENT COLLEGES

\section{A. Make Reasonable Structure of Practical Training Curriculum System}

The arrangement of practical training course should take students' ability to apply technology as its key point and highlight the importance of practical teaching. It should also adhere to the basic principle of coordinating teaching, learning and practicing together. The current condition that accounting theory does not in line with practical teaching should be coped with by methods, such as contractual programs and practice in enterprises. We should raise the proportion of practical training in the whole teaching plan of accounting major. Normative documents such as teaching plan, syllabus and the construction of curriculum that meet the needs of accounting practical training at independent colleges should be carried out. As is shown in "Fig. 1", there are three subsystems included in the accounting practical teaching system which is more systematic. They are independent specialized course practicing system, the extended comprehensive training system and social practice and professional practice system. The independent specialized course practicing system are made up by 6 courses, including Accounting Principles, Financial Accounting, Advanced Financial Accounting, Cost Accounting, Financial Management, Science of Auditing. This system is formed according to the facility value which is from simple to complicated and professional judgment of each course. The extended comprehensive training system is based on the related courses of accounting. It extends the connotation and denotation of the comprehensive simulation practice of accounting. The comprehensive emulation practice is different with normal comprehensive practices and single courses in form and content. The difference lies in that the former is more artificial, comprehensive and logistic. As stressed in the social practice and professional practice system, students are supposed to complete the task of twoweek practice in campus and at the same time, they should fully combine theories learned at school with social practice on holidays during the 2 nd to the 4th academic year or graduation practice time. By this way, application-oriented talents will be sent into society.

\section{B. The Reform of Practical Teaching Mode}

In practical teaching model, we chose group teaching, set training post according to the real post in enterprises and establish practical restraint system and accounts-checking system. All the posts are included in each groups, everyone can experience each of the post, so the students will get a better knowledge of initial control system of accounting. By the reform of practical teaching model, students can be familiar with the delivery procedure of bills, internal auditing and financial management in enterprises. That is to say, it can ensure the combination of theory with practice.

\section{The Diversification of Practical Training Courses}

The diversification of courses means that students play the principal role in class. On this condition, students will become more interested in learning. Practical training teachers should explore new ways like video teaching to carry out their accounting practical training. Through these videos, students can exactly feel the daily work and environment of accounting department in enterprises and deepen their own understanding of accountancy. What' more, we should work hard to make students more initiative and raise their capability to analyze and handle problems. What we need to do is to teach them how to make accounts, understand them and know how to use them as well. Under this effort, students can see the articulation of accounting treatment and the logic of accounting procedure. 


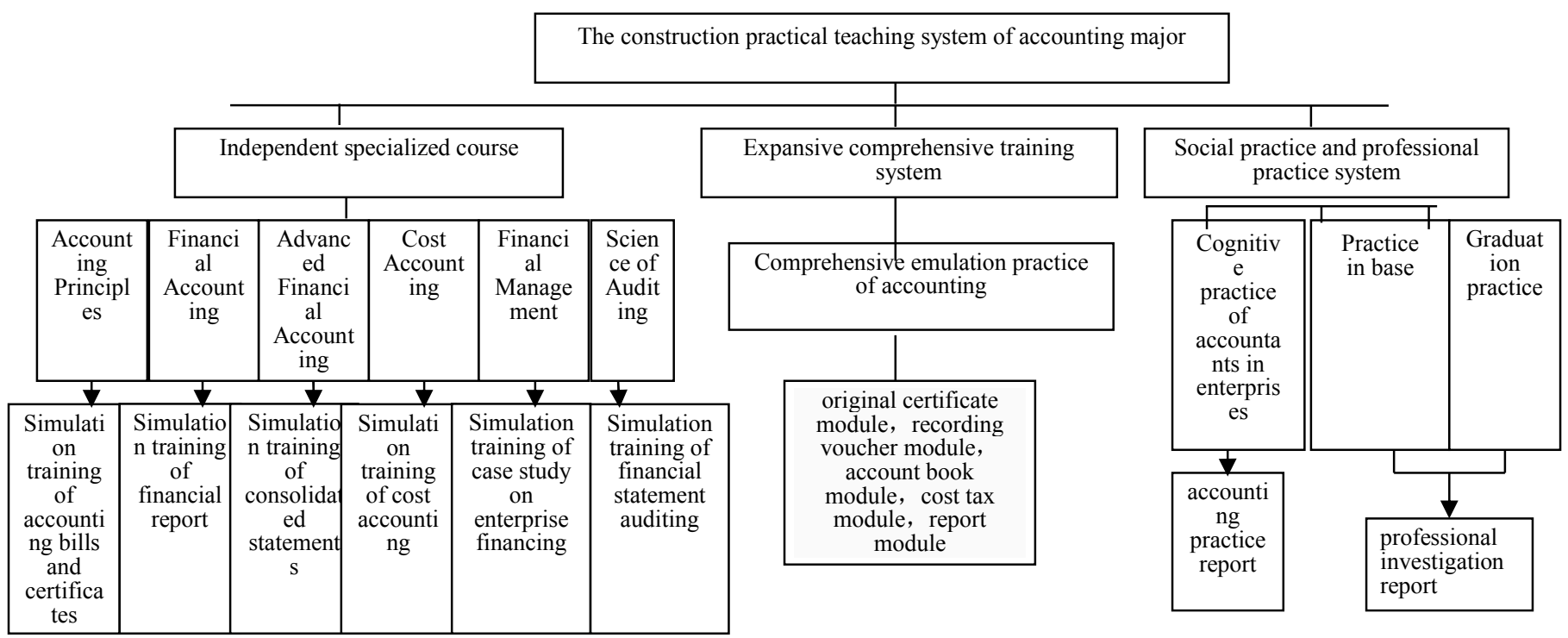

Fig. 1. Diagram of Practical Teaching System of Accounting Major of Independent Colleges

\section{Enhancement of Teachers Team}

We should raise the teachers' practical teaching level and pay attention to train professional teachers. The system that requires teachers to work in enterprises should be established and because this can help them get the knowledge of hot issues in real work. At the same time, a part-time teachers group consisted of social peer professional workers and technological experts in enterprises should be formed. We need to invite experienced technological experts from enterprises to make lectures in independent colleges and give advice to students and teachers to help them solve problems met in accounting business treatment. It is also a good choice for independent colleges to employ those accountancies with much experience as part-time teachers here. They can teach some of the practical training courses. It is sure to help optimize the structure of the current teachers and complement with the professional teams.

\section{E. Reform of Practical Training Check Method}

The examination of accounting practical training should focus on the process, instead of its result. During the practical training, teachers are required to evaluate students' performance by checking their work regularly or irregularly. They may evaluate students' work efficiency and their ability to understand and solve problems by talking with them or asking questions. They can check students' technical ability through a written test. In this kind of test, the steps of accounting practical training are picked out and work as test questions on exam papers. Students take the examination by extracting some of the test questions from all. In this case, if they want to get good score, they must have an overall knowledge of each step. So tests in this kind can help us see students' ability correctly and to some extent, prevent some students from copying.

\section{CONCLUSION}

Practical training is a key point of teaching practice of accounting major at independent colleges. Students' professional skills and integrated capabilities are closely related to the teaching quality of accounting practical training. Whether high-quality and applied talents can be sent to society or not is also determined by it. Totally, the exploration of for practical teaching based on the construction of practical teaching system of accounting major at independent colleges still has a long way to go.

\section{REFERENCES}

[1] Zheng Tian. The Construction of Practical Teaching System of Accounting at Vocational Colleges[J]. Friends of Accounting, 2011(05):119-120.

[2] Lv Xiu'e, Zhang Haixiao, Xu Haizhi. Research and Practice on the Construction of Campus Practical Teaching Method of Accounting at Vocational Colleges [J].Education and Vocation, 2010(11):161-16.

[3] Chen Hua, Xi Chenglong, Yang Guochen. Study on the Campus Practical Teaching Method of Accounting in Independent Colleges [J].Business Accounting, 2013(06):124-125.

[4] Tao Jing. The Problems and Countermeasures in the construction of Practical Teaching System of Accounting at Independent Colleges[J]. Popular Science. 2013 (11) : 123-125. 